\title{
BIOЖECHNOLOGY
}

\section{RESEARCHERS AS EDUCATORS: NEW LEGISLATION COMPELS A STRONGER ROLE}

T

The first permanent body to oversee commercialization of an aspect of biotechnology was proposed by U.S. Congressman Albert Gore in late

April. The bill, a relatively tame piece of legislation which authorizes the establishment of a President's Commission on the Human Applications of Genetic Fngineering, will result in no immediate regulation of recombinant DNA technology (see BIO/TECHNOLOGY, June 1983). Restricted to a comprehensive review of developments which have implications for human genetic engineering, the proposed commission would examine medical, legal, and ethical issues under the guidance of a panel composed of both scientists and non-scientists.

This proposed legislation is only the first of a number of Congressional actions which will determine the direction of biotechnology's development in the United States. If other countries continue to follow the trend of the U.S. government in regulating biotechnology, these actions will also set international precedents. The implications of Gore's legislation are clear: biotechnology will play an increasingly active part in the arena of political democracy. Given the unstable nature of modern politics, industrial biotechnology has cause to view its increased prominence with uneasiness. In a nation such as the United States, for example, where the President supports "Creation Science," public ignorance of biotechnology subjects industrial development to the reflexes of political rhetoric.

The solution to the problem of public lack of awareness of biotechnology cannot be left to politicians, executives, or school teachers. The educators in biotechnology have always been the researchers; their influence must be greatly expanded on a public level for biotechnology to follow a socially useful path of development. The current system for teaching future citizens about new technologies will continue to founder without participation by researchers. The sad state of secondary school education in U.S. science and engineering is characterized by a largely verbal method of learning. At its worst, students learn and memorize scientific concepts from textbooks in order to write the correct key words onto their test papers. All too often, the teacher has followed a similar course of study in his or her preparation; the heavy demands and poor rewards of secondary school teaching rapidly discourage most researchers from considering careers in this area. The process of observation, the linking of scientific concepts to visual experience, the formation and testing of hypotheses, the process of thinking about technical applications and implications-these factors require exposure to scientists and engineers, preferably in the laboratory. Researchers who have made their place in the world of biotechnology realize this when reflecting upon their early education. In order for citizens to keep pace with technological innovation and support civic leaders who favor its intelligent development, the direct exposure to researchers and their tools must become the rule rather than the exception.
If the current educational system cannot be depended upon to educate students about science and technology, researchers must take it upon themselves to work through their professional organizations and corporations and involve themselves more directly with students. These options are available for researchers who wish to participate. The New York Academy of Sciences, for example, deserves mention for two programs which its members use to improve scientific education at a secondary school level. The "Scientists in the Schools" program matches scientists from the Academy to the requests of school science supervisors in the New York metropolitan area. The program is based purely upon the needs of the students; it is not restricted to the training of the gifted. Another program, the "Science Research Training Program", places highly motivated and talented high school students in industrial and medical research laboratories during the school year and over the summer recess. BIO/ TECHNOLOGY, in an effort to promote this type of direct exposure in the fields of biotechnology, will publicize similar programs in future issues under its Announcements section. Submission of information about existing programs of this type in any country is strongly

Continued on page 436

\section{Tn5 TRANSPOSON REVIIW: CAUSE FOR A CHANGE IN FORMAT}

$\longrightarrow$ his month BIO/TECHNOLOGY has departed from its usual policy of publishing both a review article and a group of original research papers. Instead we are presenting a very comprehenive review article on the transposable element $\operatorname{Tn} 5$. Our decision to devote the entire research section of the magazine to this article was based on the importance of Tn5 as a tool for genetic engineering, the extraordinary quality and depth of the review, and the fact that no other review of $T n 5$ exists in the scientific literature. We shall resume our normal format of including both original research and review papers next month.

Transposable elements are natural gene vectors that are frequently used for the genetic engineering of bacteria, yeast, and plants. Tn 5 , which contains genes for antiobiotic resistance, is particularly useful because it is very versatile and very mobile: it can move genes easily and efficiently to a number of sites and alter expression of genes near their insertion sites. Tn 5 has been utilized for genetic manipulation of many important organisms, including the Ti plasmid of Agrobacterium tumefaciens, nitrogen-fixing bacteria, and many pathogenic bacteria. It will become an increasingly important tool for $R \& D$ in the agricultural, pharmaceutical, energy, environmental management, and other industries where gene cloning is a key to future success. The review article covers the molecular biology, specific applications, and evolutionary development of this important genetic element. 
EDITORIAL Continued from page 387

encouraged.

As biotechnology's commercialization becomes increasingly linked to public scrutiny, it is in the self-interest of researchers to actively promote direct public education in biotechnology: a public with technological savvy is more likely to support innovative research. As citizens, researchers may feel compelled to participate because improved education in science and engineering is necessary for an effective modern democracy. To borrow a term from science educator Mary Budd Rowe, fate controlthe sense that people can know about and influence the direction of society as it affects their lives-is essential for participatory democracy. The current tendency for students (and future citizens) to believe or disbelieve the textbook or verbal scientific instruction-based upon the authority of Science-works against fate control. As new technologies play an increasingly important part in rapidly transforming occupational and personal roles, scientists and engineers must accept the burden of informing future citizens directly to ensure the effectiveness of participatory government.

-Christopher Edwards

\section{SAIS REPRESTIATMES}

\section{U.S. Office}

Henry Dale

Group Advertising Director

15 East 26 Street

New York, NY 10010

(212) 689-9140

\section{U.K. Office}

Andy Sutherland

4 Little Essex Street

London WC2R 3LF

(1) $836-6633$

New England

Charles Lynch

61 Adams Street

Braintree, MA 02184

(617) 848-9306

Upstate New York

Donald E. Northrup

RD \#3 Box 6

Dalton, PA 18414

(717) 563-2572

Mid-Atlantic

Daniel Adams

3608 Chapel Road

Newton Square, PA 19073

(215) 353-6191

Mary Grunmeier

Box 1068

Edison, NJ 08818

(210) 572-9018

Southwest

Bill Powell

17202 Lazy Hill Lane

Spring, TX 77379

(713) 376-2368

\section{Southeast}

Brinker \& Brinker

$5353 \mathrm{~N}$. Federal Highway

Fort Lauderdale, FL 33308

(305) 771-0064

Midwest

Didier \& Broderick

255 Revere Drive

Suite 105/106

Northbrook, IL 60062

(312) 498-4520

\section{West Coast}

Gretchen Hasse

57 Post Street

Suite 712-715

San Francisco, CA 94104

(415) 392-6794

Dave Heidersbach

119 West Bellevue Drive

Pasadena, CA 91105

(213) 796-9200

\section{Canada}

Peter Drake

32 Front Street West

Suite 201

Toronto, Ontario M5J 1 C5 (416) 364-1623

\section{Australia}

Gus Bartel

PO Box 15

The Patch, Victoria

Australia 3792

West Germany \& Austria

Franz Schrecklinger

TMW Top Media

Werbegesellschaft Gmbh

Frankfurt (611) 726046

Holland \& Belgium

Mrs. Adele Struyck

G. Arnold Teesing BV

Amsterdam (020) 263615

Switzerland

Werner Stahli

Agentur IFF AG

Schaffhausen (053) 45821

Scandinavia

Andrew Karnig

Andrew Karnig \&

Associates AB

Stockholm (08) 516860

Japan

Mashy Yoshikawa

Orient Echo, Inc.

Tokyo 54 1-4923

COMMENTARY Continued from page 416

tic acid, acetic acid, ammonia, ethyl alcohol, and biochemical oxygen demand probes used for these purposes in Japan. The commercially promising models listed by Dr. Anthony Turner of Cranfield Institute of Technology detect substances ranging from lactic acid (for use in sports medicine) to TNT (for use in anti-terrorist work). My guess is that an equal dividend from this burgeoning technology could be the insight it provides into organicinorganic interrelations. This is essential groundwork if the dizzy goal of true bioelectronics is to be achieved.

FINAL WORD Continued from page 454

monplace to observe the inbreeding depression of time serving "cover your rear" bureaucracies and of gridlocked administrators who unwittingly shield the "deleterious recessives" from too much exposure to selection pressure. While this was the Lysenko story, private organizations can suffer similar fates.

Building a polity in the biotechnology community, at any level, means keeping the heterogeneous nature of the culture in a healthy balance. A culture of collective sameness (which usually develops mimicry into its principal survival skill) creates little that is new. The trick is to keep our heterogeneous community from flying apart or disemboweling itself. Just think of all the short sighted investors, greedy brokers, closet Marxists, threatened hacks, over-reaching egotists, cheap-shot competitors, ambitious politicians, and idiotic fantasy mongers swimming in the pond. (This is the short list). But after all, it is in part the chaotic nature of capitalism that is responsible for its creative vigor. Personally, I think it's coming together beautifully.

\section{TECHNOLOGY REPORTS}

$\mathrm{BIO} / \mathrm{TECHNOLOGY}$ invites its readers to submit manuscripts for the Technology Report section of the publication. These reports, which vary in length from 500 to 4000 words, should address a specific issue or subject and be written for a general readership that includes industrial and academic researchers, project managers and corporate planners, marketing executives, investors, and financial advisors. Decision to publish will be at the discretion of the editor. Manuscripts and queries should be addressed to the editor and sent to:

\section{BIO/TECHNOLOGY}

15 East 26th Street

New York, New York 10010

BIOTECHNOLOGY
4 Little Essex Street London WC2R 3LF U.K. 